\title{
PATH ANALYSIS ON GESTATIONAL SOCIO-ECONOMIC DETERMINANTS OF NUTRITIONAL STATUS IN CHILDREN UNDER FIVE IN PURWOREJO REGENCY, CENTRAL JAVA
}

\author{
Ika Yuli Ayuningrum ${ }^{1)}$, Harsono Salimo²), Yulia Lanti Retno Dewi3) \\ ${ }^{1)}$ Masters Program in Public Health, Sebelas Maret University \\ 2)Department of Pediatrics, Dr. Moewardi Hospital, Surakarta \\ 3)Department of Nutrition, Faculty of Medicine, Sebelas Maret University
}

\begin{abstract}
Background: Undernutrition by height-for-age standard starts during pregnancy and continues to the first two years of life. Linear growth disorders among children under five years are associated with morbidity, mortality, loss of physical growth potential, reduced neurological development, reduced cognitive functions, and increased risks of adulthood chronic diseases. In 2015, the number of undernourished children under five (height-for-age) reached 156 million globally. Purworejo regency was an area with the second highest undernutrition cases in Central Java in 2014. This study aimed to analyze the life-course epidemiology perspectives on the socio-economic factors contributing to the nutritional status of the children aged two to five years in Purworejo regency, Central Java.

Subjects and Method: This was an observational analytical study with case control design. This study was conducted in Purworejo, Kaligesing, and Bruno sub-districts, Purworejo Regency, Central Java in February to March 2017. A total sample 160 children aged two to five years and their mothers were selected by fixed disease sampling. There were 37 children in the case groups, and 113 children in the control groups. The independent variables included family income, maternal age, maternal nutritional status (mid upper arm circumference), birth length, exclusive breastfeeding and the children's history of illness. The dependent variable was the children's nutritional status (height-for-age/HAZ). Data on the children's height were collected using microtoise. Other data were collected by maternal and children health $(\mathrm{MCH})$ books and a set of questionnaires. The data were analyzed using path analysis. Results: Nutritional status of children under five (height-for-age/HAZ) was affected by family income ( $\mathrm{xp} 100,000)(\mathrm{b}=0.03 ; \mathrm{SE}=0.24 ; \mathrm{p}<0.001)$, maternal age (years) $(b=0.02 ; \mathrm{SE}=0.02 ; \mathrm{p}=0.160)$, maternal nutritional status/MUAC $(\mathrm{cm})(\mathrm{b}=0.08 ; \mathrm{SE}=0.05 ; \mathrm{p}=0.066)$, birth length $(\mathrm{cm})(\mathrm{b}=$ $0.22 ; \mathrm{SE}=0.05 ; \mathrm{p}<0.001)$, exclusive breastfeeding $(\mathrm{b}=0.03 ; \mathrm{SE}=0.16 ; \mathrm{p}=$ $0.080)$, and the absence of illness $(b=0.39 ; \mathrm{SE}=0.14 ; \mathrm{p}=0.007)$.

Conclusion: Nutritional status of the children under five (height-forage/HAZ) is affected by family income, birth length, exclusive breastfeeding, maternal age, maternal nutritional status, and the absence of illness.
\end{abstract}

Keywords: nutritional status, children under five, life-course epidemiology, socio-economic

Correspondence: Ika Yuli Ayuningrum. Masters Program in Public Health, Sebelas Maret University, Jl. Ir. Sutami 36 A, Surakarta 57126, Central Java, Indonesia. Email: ayuningrumo811@gmail.com. Mobile: +6285729407360. 